\title{
Epidemiological Characteristics of Animal Bite Cases Recorded by Case based Surveillance in Iraq 2012
}

Thane Muhsen

Background: Animal bite is one of the public health problems all over the world, especially in poor countries. Animal bites have an impact on human health due to rabies disease, which is a viral transmitted disease from animal to human with a high mortality rate.

Objective: To determine the epidemiological characteristics of animal bite cases by person, time, and place.

Method: Descriptive cross sectional study was done by reviewing cases caused by animal bites., Data including the demographic characteristics of age, gender, occupation, site of bite, and attending health institutions searching treatment were all included.

\section{ABSTRACT}

Results: There were 11600 animal bite cases. Most of bites caused by stray dogs $11577(99.8 \%)$, and the males were more affected than females. The mostly affected site of bite was lower limbs. Babylon and Naniva provinces registered the highest rate of animal bite victims.

Conclusion: The study is determining the epidemiological characteristics of animal bite cases by person, time, place and giving an accurate view about the epidemiological importance of the problem in Iraq. Key words (Rabies, Control Center, Post Exposure Therapy (PEP, Animal Bites)

\section{INTRODUCTION}

Animal bite is one of the public health problems worldwide $^{(1)}$. WHO has acknowledged that there are about 10 million people taking rabies vaccines annually in the poorest countries. This large number of vaccine consumption is considered of high cost. All over the world, about 65,000-87,000 (mostly in developing countries) deaths have occurred annually due to rabies caused by animal bites ${ }^{(2)}$. Asia has experienced about 38,000 to 60,000 deaths per year, where India accounts for the majority of deaths of more than 22,000. - 37,000 deaths annually) ${ }^{(2,3)}$. In Latin America there is a joint program for regional epidemiological surveillance of the control and treatment of animal bites and rabies disease in collaboration with the Pan American Health Organization (PAHO / WHO). The Global Alliance for Rabies Control ${ }^{(4)}$ has been working on this program since 1981, focusing on vaccination campaigns for dogs, raising community awareness about the disease and providing free vaccine, resulting in reduced incidence of rabies disease to about $95 \%$ $(4,5)$. In Iraq before 2012 , the data was sent to $\mathrm{CDC} /$ Zoonotic disease as an aggregated data by which no beneficial statistical analysis can be done. The objective of this study is to determine the epidemiological characteristics of animal bite cases by person, time, place and giving an accurate view about the epidemiological importance of the problem in Iraq. The justification of the study is to firstly establish a database on this serious preventable public health problem that was not adequately controlled. Secondly, to know the extent and tendency of animal bites cases registered in Iraq. Thirdly, to inform the decision-makers of the health authorities in the ministry of health about the magnitude of this health problem. Finally, to raise awareness about the problem among workers in all health institutions.

\section{METHODS}

Training: A training course was held to healthcare workers in zoonotics units in all Iraqi provinces about the data entry on the Excel sheet program and sent monthly to the zoonotic disease section in CDCs, for epidemiological analysis.

Study design: Retrospective cross-sectional descriptive study of animal bite cases, Iraq, 2012. Case definition: Animal bite case is defined as all victims exposed to animal bites attending health institutions (primary healthcare centers, districts, hospitals).

Study area: All Iraqi provinces were included in the study. 
Study sample: All victims of animal bites attending to health institutions searching for

treatment were included, regardless the date of the bite.

Study Period: From $1^{\text {st }}$ of January 2012 to $31^{\text {st }}$ of December 2012.

Data collection: A special form of Excel sheet list was designed to collect animal bite cases data, including the demographic characteristics of bitten victims regarding age, gender, occupation, site of bite, completed and uncompleted PEP (Post Exposure Prophylaxis) schedule, types of animals.

Ethical consideration: Informed consent of all patients was taken for using their data without reference to the personal specifications this was done when patients came for treatment requirement.

\section{RESULTS}

After the application of the epidemiological case based surveillance program for animal bites in Baghdad and other provinces, 11660 animal bite cases, and 10 cases of rabies have been registered in 2012. The majority of the mentioned records was due to stray dogs $11577(99.8 \%)$, other animals $23(0.2 \%)$ as depicted in table (2). The male victims recorded 8846 (76.26\%), while females 2754 (23,74\%)

with ratio (3:2) as demonstrated in table (1). The most vulnerable age group was between $17-49 \mathrm{yr}$ $(35.21 \%)$. The most site of bite was the lower limbs 7637 (65.5\%), followed by upper limbs $2298(19.7 \%)$, trunk 737(6.3\%), respectively as shown in Graph (2). The rate of rabies in Iraq was 0.292 / 1000000, while the animal bites incidence rate was $34.08 / 100000$ according to the population census by provinces in year 2012 . Babylon Province recorded the highest rate of animal bites (2090) (18.02\%) followed by Dywania (1539) (13.26\%), Naniva 1377(11.87\%), Karbala (1143) (9.85\%). The government of Dahuk, Sulaymaniyah reported zero animal bite, see table (3).

The study also showed that those who had the first dose were $\mathrm{N}=(5750),(49.31 \%)$, who had two doses $\mathrm{N}=(2179)(18.69 \%$, who had all five vaccine doses were $\mathrm{N}=1098(9.42 \%)$. This study also revealed that the most occupation of high risk prone to animal bites was children $\mathrm{N}=4419$ (38.4\%), followed by students $\mathrm{N}=3151(27 \%)$ and the least was police $\mathrm{N}=139(1.2 \%)$, see Table (4).

Table 1: Frequency distribution of study sample by age group, gender and type of bites and vaccines status. Rabies Immunoglobulin (RIG)

\begin{tabular}{lcc}
\hline \hline \multicolumn{1}{l}{ Variable } & & \\
\hline $\begin{array}{l}\text { Age group (years) } \\
\text { (total=11600) }\end{array}$ & $\mathbf{N}$ & $\boldsymbol{\%}$ \\
\hline Preschool (<5) & 922 & 7.95 \\
Children (5-9) & 2460 & 21.20 \\
Teenagers (10-16) & 3413 & 29.42 \\
Young adults (17-49) & 4058 & 35.21 \\
Middle age (50-69) & 620 & 5.34 \\
Elderly (70+) & 127 & 1.09 \\
\hline Gender (total=11600) & & \\
\hline Male & 8846 & 76.26 \\
Female & 2754 & 23.74 \\
\hline Type of bites (total=11600) & $\mathbf{N}$ & $\mathbf{\%}$ \\
\hline Single & 8486 & 73.16 \\
Multiple & 2958 & 25.50 \\
Blank & 129 & 1.11 \\
\hline
\end{tabular}




\begin{tabular}{|c|c|c|}
\hline $\begin{array}{l}\text { Vaccination status } \\
(\text { total }=11600)\end{array}$ & $\mathbf{N}$ & $\%$ \\
\hline $\begin{array}{l}\text { Complete schedule (full five } \\
\text { doses) }\end{array}$ & 1098 & 9.47 \\
\hline $\begin{array}{l}\text { Incomplete schedule (<five } \\
\text { doses) }\end{array}$ & 10502 & 90.53 \\
\hline \multicolumn{3}{|l|}{ Number of doses (total $=11600)$} \\
\hline $1^{\text {st }}$ dose & 6098 & 52.56 \\
\hline $2^{\text {nd }}$ dose & 2588 & 22.31 \\
\hline $3^{\text {rd }}$ nose & 1731 & 14.92 \\
\hline $4^{\text {th }}$ dose & 1183 & 10.46 \\
\hline \multicolumn{3}{|c|}{ RIG (Rabies immunoglobulin (total= 11600) } \\
\hline Yes & 3429 & 29.41 \\
\hline No & 545 & 4.67 \\
\hline Blank & 7626 & 65.74 \\
\hline Total & 11600 & 100.0 \\
\hline
\end{tabular}

* RIG usually given once in addition to $1^{\text {st }}$ dose of vaccine with special indications likes site of bite e.g head, macerated wounds, child age and others. Meaning that not all bitten victims required to have RIG.

Table (2): Study sample distribution by types of animals

\begin{tabular}{|c|c|c|}
\hline $\begin{array}{c}\text { Type of } \\
\text { animals }\end{array}$ & $\mathrm{N}$ & $\%$ \\
\hline dog & 11577 & 99.8 \\
\hline cat & 16 & 0.14 \\
\hline horse & 2 & 0.02 \\
\hline cow & 3 & 0.03 \\
\hline rat & 2 & 0.02 \\
\hline Total & 11600 & 100 \\
\hline
\end{tabular}

Frquency distribution of victims by provinces, Iraq, 2012 2090

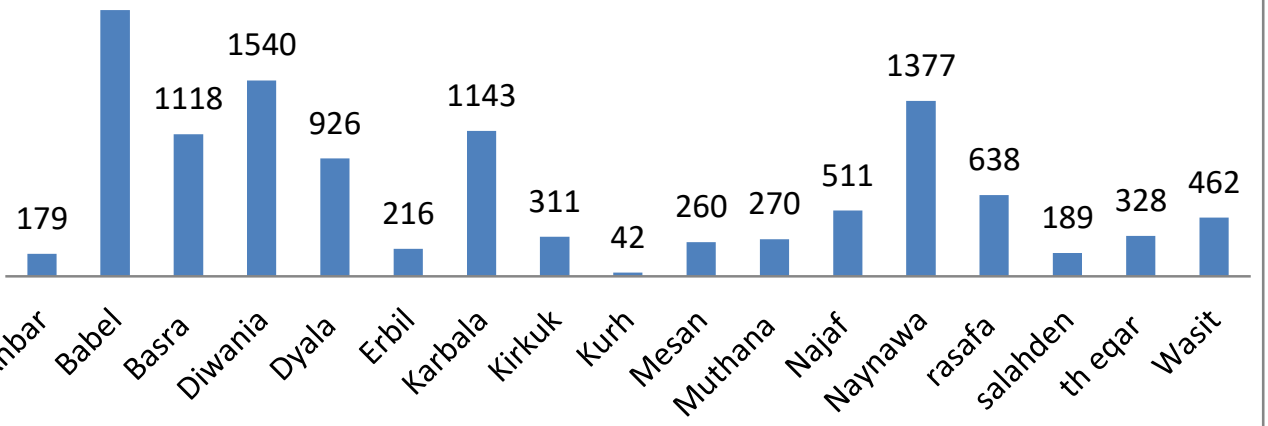


Graph (1): distribution of animal bites by governorates Iraq in 2012 Table (3): Animal bites, Rabies cases distribution in Iraq provinces 2012

\begin{tabular}{|c|c|c|c|c|}
\hline Provinces & Population & $\begin{array}{c}\text { No. of animal } \\
\text { bites }\end{array}$ & $\begin{array}{c}\text { Animal } \\
\text { bites } / \mathbf{1 0 0 0 0}\end{array}$ & $\begin{array}{l}\text { Rabies } \\
\text { cases }\end{array}$ \\
\hline Naniva & 3353875 & 1374 & 40967 & 1 \\
\hline Kirkuk & 143747 & 311 & 21760 & 0 \\
\hline Dayala & 1477684 & 925 & 2.2956 & 0 \\
\hline Anbar & 1598822 & 179 & 11195 & 0 \\
\hline Baghdad & 755278 & 719 & 09910 & 2 \\
\hline Babylon & 1864124 & 2090 & 117117 & 2 \\
\hline Karbla & 1094218 & 1143 & 104453 & 0 \\
\hline Wasit & 124036 & 452 & 372995 & 0 \\
\hline Salh deen & 1442661 & 176 & 12951 & 0 \\
\hline Najaf & 131608 & 510 & 36450 & 1 \\
\hline Diwanya & 1162485 & 1539 & 138831 & 0 \\
\hline Muthana & 735216 & 270 & 39271 & 0 \\
\hline Th-qar & 1883160 & 318 & 16886 & 0 \\
\hline Messan & 994710 & 260 & 27107 & 0 \\
\hline Basra & 2601960 & 1118 & 42970 & 1 \\
\hline Erbil & 1657684 & 206 & 13030 & 3 \\
\hline Dahuk & 1158633 & 0 & 0 & 0 \\
\hline Sulaymania & 193162 & 0 & 0 & 0 \\
\hline Total & 342062 & 11600 & 34086 & 10 \\
\hline
\end{tabular}

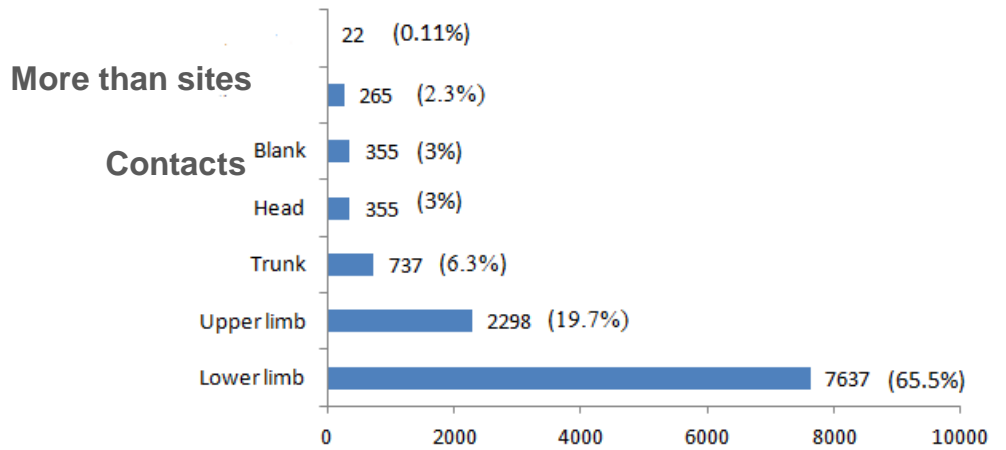

Graph (2): Study sample distribution by sites of bites Iraq 2012 


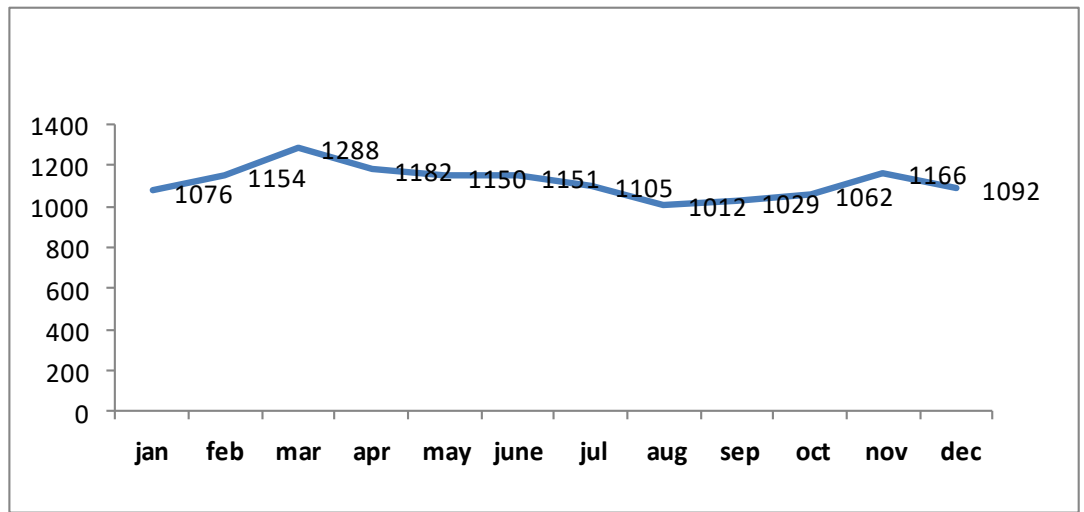

Graph (3): distribution of victims by month, Iraq, 2012, which shows
that there was no obvious Seasonal variation in animal bites cases.

Table (4) distribution of study sample by occupations

\begin{tabular}{|c|c|c|}
\hline occupation & frequency & $\%$ \\
\hline student & 3151 & $27 \%$ \\
\hline Housewife & 944 & $8.1 \%$ \\
\hline Children & 4419 & $38.4 \%$ \\
\hline privet work & 2019 & $17.9 \%$ \\
\hline officer & 856 & $7.4 \%$ \\
\hline police & 139 & $1.2 \%$ \\
\hline Total & 11600 & $100 \%$ \\
\hline
\end{tabular}

\section{DISCUSSION}

The study revealed that the main cause of the bites was stray dogs constituting $99.8 \%$ of all animal bites, similar to neighboring countries as India and other Asian countries $(91.5 \%)^{(6,7)}$, Jordan $(50 \%)^{(8)}$. It is clear that nearly the same or more as in Jordan .There is no significant seasonal variation of bites as shown in graph (3), which is similar to what was recorded in studies conducted in the KSA( Kingdom of Saudi Arabia) but different in India, where it increases during May and October ${ }^{(9-12)}$. The age groups of

high risk of animal bites were young adults 4058 $(35.21 \%)^{(6)}$ as in Table (1), In this study, the incidence rate was $34.1 / 100000$ mostly due to stray dogs while in India (17.4 per 1000) and in Jordan $(50.8$ per 100,000$){ }^{(6,7) .}$

It is also observed that males are more exposed to bite than females with ratio $(3: 2)$; likes studies in
India (2:1), Jordan(3:1), Saudi Arabia(4:1)as they are neighboring to Iraq within the Eastern Mediterranean Region Graph (1). This is also found in similar studies conducted in India ${ }^{(6,7)}$, Jordan ${ }^{(8)}$, Pakistan ${ }^{(1,6)}$ and Turkey ${ }^{(13) .}$

The most common sites of the victim's body were the lower limbs, the upper limbs, the trunk, and head. These findings are similar to studies conducted in Turkey ${ }^{(14,15)}$, Jordan and Iran ${ }^{(6,8)}$. was more than those who had one ,two, three, four and the five dose which the least, which demonstrates the need to raise the awareness of the community towards the completion of the vaccine schedule through cooperation with the zoonotic units in all Iraqi provinces to promote community health education by distribution folder, posters and educational campaigns to special society like students in schools.

We noticed that the most occupation of high risk prone to animal bites was children, followed by 
students and the least was police look to Table (5) .This is might be because they usually either playing with animals or can't defend themselves against attacks of furious animals and dogs in particular.

\section{CONCLUSION}

The study gave us a view and the results of first application of the epidemiological surveillance of animal bite cases in Iraq with available data to perform statistical analysis, and the identification of the size, determinants of this public health event according to person, place and time, which is of high risk to cause rabies a viral disease of high mortality rate reaching up to $100 \%$.

\section{Recommendations:}

1. Strengthening epidemiological surveillance of the animal bite cases.

2. Developing the abilities of all employees in zoonotic units in all Iraqi provinces by

3. establishment the training workshops on Excel program.

4. Ensuring of completeness and timeliness of the data.

\section{REFRENCES}

1. R. C. A Shetty, S Singh,, "Profile of animal bite cases in Pune," The Journal of communicable diseases, vol. 37, pp. 66-72, 2005.

2. G. K. Vyas Sheetal, Bhatt Gneyaa, Tiwari Hemant "Animal Bite management Practices: Study at Three Municipal Corporation Hospotals of Ahmedabad.," National Journal of Community Medicine, vol. 1, no. 2, 2010,

3. C. S. Knobel D. L, Coleman P. G, Fevre E. M, Meltzer M. I, Miranda M. E, Shaw A, Zinsstag $\mathrm{J}$, Meslin F. X., "Re-evaluating the burden of rabies in Africa and Asia," (in eng), Bull World Health Organ, vol. 83, no. 5, pp. 360-8, May 2005.

4. reginol office for the Americas. Available: http;/www.paho.org. (Accessed on 01 Nov 2018)

5. L. L. F. Belotto A, Schneider M. C, Tamayo H, Correa E., "Overview of rabies in the Americas," (in eng), Virus Res, vol. 111, no. 1, pp. 5-12, Jul 2005.
6. J. I. Yousaf Iqra, Hussain Raja., "FREQUENCY AND RECOMMENDATION TO CONTROL DOG BITE INJURIES IN ISLAMABAD PAKISTAN," Gomal University Journal of Research, vol. 33, no. 2, pp. 78-84, 2017.

7. Dodet B, Goswami A, Gunasekera A, de Guzman F, Jamali S, Montalban C, Purba W, Quiambao B, Salahuddin N, Sampath G, Tang Q. Rabies awareness in eight Asian countries. Vaccine. 2008 Nov 25;26(50):6344-8.

8. H. K. Haddadin S. Hussein, A. Mhedat, M. AlRashdan, M. Al-Nasour, B. Al-Hajawii, "Animal bites and animal rabies surveillance Jordan, 2000-2007.".

9. Z. A. Memish, A. M. Assiri, and P. Gautret, "Rabies in Saudi Arabia: a need for epidemiological data," International Journal of Infectious Diseases, vol. 34, pp. 99-101, 2015/05/01/ 2015.

10. N. S. Sreenivas, S. Sakranaik, R. T. Sobagiah, and A. Kumar, "An epidemiology of animal bite cases attending tertiary care centre of Bangalore Medical College and Research Institute, Bengaluru: a retrospective study," 2017, Rabies, Animal bite, Monthly distribution, Prevention vol. 4, no. 7, p. $5 \%$ J International Journal Of Community Medicine And Public Health, 2017 . 06-23 2017.

11. Pavithra R, Viveki RG, Halappanavar AB. Socio Demographic Profile and Management Practices of Animal Bite Cases Attending Anti Rabies Clinic in a Tertiary Care Centre in North Karnataka. IJAR. 2015;5(1):371-.

12. Acharya R, Sethia R, Sharma G, Meena R. An analysis of animal bite cases attending antirabies clinic attached to tertiary care centre, Bikaner, Rajasthan, India. International Journal Of Community Medicine And Public Health. 2016 Dec 28;3(7):1945-8.

13. F. A. Janani A. R, Simani S, Farahtaj F, Eslami N, Howaizi N, Biglari P, Sabetghadam M., "Epidemiology and control of rabies in Iran," (in eng), Dev Biol (Basel), vol. 131, pp. 207-11, 2008.

14. U. H. Johnson N, Fooks A. R, Freuling C, Muller T, Aylan O, Vos A., "Rabies epidemiology and control in Turkey: past and present," (in eng), Epidemiol Infect, vol. 138, no. 3, pp. 305-12, Mar 2010.

15. Seimenis A, Morelli D, Mantovani A Zoonoses in the Mediterranean region. Annali dell'Istituto superiore di sanità. 2006;42(4):43745. 